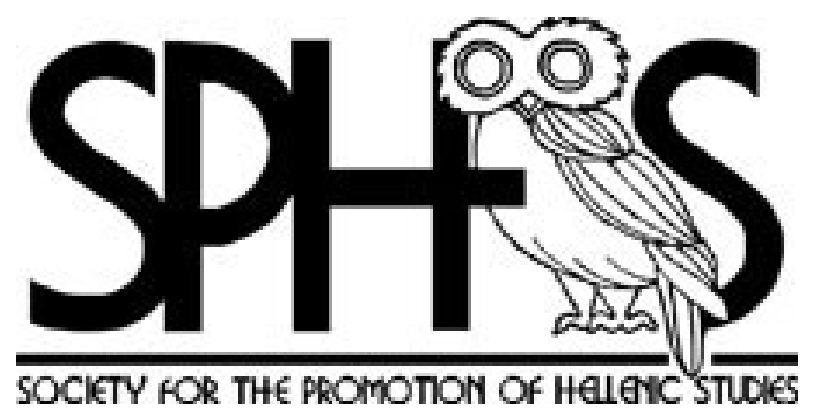

Königlichen Museen zu Berlin. Beschreibung der Vasensammlung im Antiquarium by Adolf Furtwängler

Review by: J. E. H.

The Journal of Hellenic Studies, Vol. 8 (1887), pp. 289-290

Published by: The Society for the Promotion of Hellenic Studies

Stable URL: http://www.jstor.org/stable/623465

Accessed: 08/01/2015 06:25

Your use of the JSTOR archive indicates your acceptance of the Terms \& Conditions of Use, available at

http://www.jstor.org/page/info/about/policies/terms.jsp

JSTOR is a not-for-profit service that helps scholars, researchers, and students discover, use, and build upon a wide range of content in a trusted digital archive. We use information technology and tools to increase productivity and facilitate new forms of scholarship. For more information about JSTOR, please contact support@jstor.org.

The Society for the Promotion of Hellenic Studies is collaborating with JSTOR to digitize, preserve and extend access to The Journal of Hellenic Studies. 


\section{Königlichen Museen zu Berlin. Beschreibung der Vasen- sammlung im Antiquarium. Von Adolf Furtwängler. Mit 7 Tafeln, 2 Bände. Berlin, W. Spemann.}

The first volume of the old Catalogue of the Vases in the Antiquarium at Berlin was issued by Lezevow in 1834; the last supplement, by Gerhard, appeared in 1846. Since that date the collection has been enriched by upwards of a thousand vases. It would have been easy to furnish a new supplement, and thereby add another element of confusion to the student. The Direction of the Berlin Museum felt, however, that the time was come for a fresh departure. A catalogue in the present state of science must no longer be merely a printed inventory, it must be a classification-a register not only of material, but of the high-water mark of opinion as regards the ordering of that material.

Berlin boldly leads the way; the other great vase collections; of Eirope can scarcely refuse to follow. Criticism of the particular classification he adopts Dr. Furtwängler provisionally deprecates. He had intended to preface each class with a statement of the grounds on which he based his arrangement. He-wisely we think - modified his plan, and the classification now challenges opinion without its substructure of theory. This theory he promises to embody in a hand-book, the appearance of which will be eagerly looked for; till then, criticism may fairly wait. No one would be more disappointed than Dr. Furtwängler if new material and further study did not modify opinion. While a catalogue remained a statement of fact, a correction was the confession of a blunder; now that to fact it adds theory, to correct is often merely to register advance.

Without attempting to criticise, we may note that to the amateur Dr. Furtwängler's classification will probably appear excessively minute. Under four universally accepted heads he has thirty-five subdivisions, and, to take one example, $C$. Altattische rotfigurige Vasen. II. der schöne Stil, ältere Hälfte-in itself, one of the thirty-five subdivisions-has within it no less than eighty-five further subdivisions ; in fact, it frequently happens that a vase has a sub-class to itself. This minuteness has, however, a double justification. First, the catalogue is manifestly so framed as to be a basis for the classification of all vases, not merely those in the Berlin collection. Sub-heads sparsely represented there may be of large content elsewhere. Secondly, minute classification tends to economise space. Vain repetition is the besetting snare of the catalogue compiler; the ideal catalogue notes in respect to individual specimens only H.S.-VOL. VIII. 
variation. In the troublesome terminology of decoration, Dr. Furtwängler makes an effort after brevity and precision. $\mathrm{He}$ adopts Lau, Die griechischen Vasen, as his system; and surely, till a better system appears, we might all do the same, and employ uniformly such convenient terms as Punktrosette, Stabornament, Netzornament, for certain familiar, decorative schemes. The admirable brevity of his descriptions can only be appreciated by those who know the difficulty of the work. The body of the catalogue is preceded by a preface stating the general plan, and by a history of the growth of the collection. It is followed by a series of excellent registers, drawn up by Dr. Wernicke. These include a comparative table of the numbers in the old and new catalogue, an index of shapes, of provenance, of inscriptions with the exception of proper names and of subjects. It seems a pity not to have given a separate index of potters' signatures: these are included under the general head of proper names. Dr. Furtwängler has not seen his way to what we may hope for in the future-a register of type forms as well as subjects. By this catalogue, as a monument of patient and accurate labour, Dr. Furtwängler has deserved well of his country. Of the book, as a testimony to his insight and ability, till his promised handbook appears, we cannot speak.J. E. H.

\section{Die Griechischen Vasen mit Meistersignaturen. Von}

Wilmelm Klein. Zweite Vermehrte und Verbesserte Auflage. Wien, Gerold, 1887.

IN speaking of the second edition of Dr. Klein's Meistersignaturen, I shall confine myself rigidly to the new material which now appears. Presumably the altered form of the book is due to a desire for uniformity with the new edition of the Euphronios. It is a uniformity deeply to be regretted. Any one who has used the old Meistersignaturen, with its ample pages and easy conspectus, its ready facilities for comparison, will regret the wearisome turning of pages, the reference forward and back necessitated by the new form. However, form is a trifle, and in substance the new edition makes a marked advance. The main sources of the advance are, Dr. Klein notes, the issue of the new Berlin Catalogue, the important papers by P. Meier, A. Z. 1884, s. 237 , and 1885 , s. 179 ; and, in a less degree, Wernicke's Beiträge, A. Z. 1885, s. 2 and 9, besides a host of minor references that have reached him from scattered museums and individual archæologists. Briefly, the sum of the new material is this: In place of 88 signatures in the old edition we have now 96 ; 